УДК $378.147+502.5$

DOI:

Валентина Самілик, аспірант кафедри теорії і методики викладання природничих дисииплін Глухівського національного педагогічного університету імені Олександра Довженка

\title{
ФОРМУВАННЯ ГОТОВНОСТІ МАЙБУТНІХ УЧИТЕЛІВ БІОЛОГІЇ ДО ПРИРОДООХОРОННОЇ ДІЯЛЬНОСТІ МЕТОДОМ КЕЙСІВ
}

Підготовка майбутніх учителів біології до природоохоронної діяльності є органічною складовою професійної підготовки сучасного фахівия. У свою чергу ие детермінує потребу в модернізаціі організаційно-педагогічних умов освітнього прочесу, пощуку професійно-орієнтованих форм та методів навчання і виховання.

У статті обтрунтовано актуальність підготовки майбутніх учителів біологї до природоохоронноі діяльності. Висвітлено вклад науковців у реалізацію иього аспекту. Обтрунтовано особливе значення професійно-орієнтованих методів в освітньому процесі. Визначено основні функиї̈ кейс-методу в контексті формування готовності до природоохоронної діяльності.

Ключові слова: готовність до природоохоронної діяльності; професійна підготовка; майбутні учителі біології; професійно-орієнтовані методи; кейс-метод.

Puc. 1. Лim. 7.

Valentyna Samilyk, Postgraduate Student of the Theory and Methods of Teaching of Natural Sciences Department Hlukhiv Oleksander Dovzhenko National Pedagogical University

\section{FORMING OF READINESS OF FUTURE TEACHERS OF BIOLOGY TO THE ENVIRONMENTAL PROTECTION ACTIVITIES USING THE CASE METHOD}

An environmental protection activity is an important part of the implementation of the paradigm of the co-evolution of nature and society. Education is the social institution through which it is possible to form the necessary knowledge, skills and abilities of citizens.

The training of future teachers of Biology to the environmental protection activity is an integral part of a modern specialist professional training. This determines the need for modernization of organizational and pedagogical conditions of the educational process, the search of the professional-oriented forms and methods of education and upbringing.

The complex development of the cognitive sphere of the individual contributes to professional lability, rapid adaptation to non-standard situations. In this context, we attach fundamental importance to education. In order to improve the theoretical training, development of analytical, communicative, organizational skills, acquiring practical experience in the professional training of future teachers of Biology, a system of educational cases for environmental protection was introduced.

The algorithm of the implementation of educational cases includes such items as getting to know the problem, necessary information collecting, finding effective ways of implementation, achieving a practical result, a report on the done work. The evaluation takes into account the activity of the working groups members, the speed and quality of the solved tasks, the ability to substantiate their own ideas and conclusions, the creativity and originality of the proposed solutions, the practical solution of the case, informativeness, scientific presentation of the results of the work performed, adherence to the ethics of communication, discussion, cooperation.

Among the main functions of educational cases of environmental protection, we define the following. cognitive, motivational, educational, organizational, reflexive, axiological, approbation, vocational guidance.

Keywords: readiness to environmental protection activities; professional training; the future teachers of Biology; the professional-oriented methods; case-method.

П остановка проблеми. Парадигма коеволюції природи й суспільства набуває дедалі більшої актуальності. Це підтверджується низкою статистичних даних, що оприлюднюються фахівцями міжнародного рівня в галузі охорони природи [5]. У наш час найпоширенішими загрозами для популяцій $є$ деградація земель, збільшення площі пустель, забруднення поверхневих і підземних вод, атмосферного повітря та ін. В одному з останніх звітів WWF “Жива Планета” зазначається: “запаси природного капіталу є самопідтримуючими. Але зростання антропогенного тиску - наприклад, перетворення природного ареалу на сільськогосподарські угіддя, надмірне рибництво, забруднення прісної води промисловими 


\section{ФОРМУВАННЯ ГОТОВНОСТІ МАЙБУТНІХ УЧИТЕЛІВ БІОЛОГЇ̈ ДО ПРИРОДООХОРОННОЇ ДІЯЛЬНОСТІ МЕТОДОМ КЕЙСІВ}

об'єктами, урбанізація та виснажливе сільське господарство і риболовля - скорочують природний капітал швидше, ніж він може відновитись" [5]. Наразі стоїть питання про формування екоцентричного світогляду суспільства, що можливо реалізувати шляхом освітньої та просвітницької діяльності. Знати, вміти і діяти - три взаємодоповнюючі ядра успішного досягнення окресленої цілі. Мета повної загальної середньої освіти, як зазначається у відповідному законі, полягає в забезпеченні всебічного розвитку, виховання і соціалізації особистості, яка здатна до життя в суспільстві та цивілізованої взаємодії з природою [4]. Не менш важливий аргумент про причетність освітян до проблеми охорони навколишнього природного середовища витікає з зазначеного С. О. Люленко: “найбільша кількість природоохоронних організацій працюють за такими напрямами, як екологічна освіта та виховання..., інформування та природоохоронна пропаганда, природоохоронні акції тощо... Численні природоохоронні організації займаються екологічною журналістикою самі або взаємодіють зі 3МI. Значна кількість природоохоронних організацій спрямовує свою діяльність на вирішення проблем збалансованого розвитку й раціонального природокористування..." [6].

Отже, підготовка майбутніх учителів біології до природоохоронної діяльності є органічної складовою професійної підготовки сучасного фахівця. У свою чергу це детермінує потребу в модернізації організаційно-педагогічних умов освітнього процесу, пошуку професійноорієнтованих форм та методів навчання i виховання.

Аналіз основних досліджень і публікацій, в яких започатковано розв'язання даної проблеми і на які спирається автор. Теорія і методика професійної підготовки майбутніх учителів біології до природоохоронної діяльності за останні роки набули особливої уваги серед науковців-педагогів: О.М. Байрак (науковометодичні засади природоохоронної освіти); Л.І.Білик (теоретико-методичні основи формування екологічної відповідальності студентів); В. М. Боголюбов (соціально-екологічні аспекти формування професійної компетентності магістрів-екологів в контексті парадигми сталого розвитку); Я.І. Габєв (природоохоронна освіта учнів у процесі вивчення біологічних дисциплін); О.М. Захлєбний (педагогічні умови впровадження природоохоронної освіти); С.О. Люленко (підготовка майбутнього вчителя природничих дисциплін до природоохоронної роботи в загальноосвітній школі); О.П. Мітрясова (стратегія розвитку екологічної освіти); С.В. Совгіра (формування екологічного світогляду майбутніх учителів у вищих педагогічних навчальних закладах); С.Д. Рудишин (біологічна складова підготовки еколога у ВН3; екологічна компетентність; природничо-наукова картина світу); I.М. Коренева (екологічна освіта для сталого розвитку); Е.Ю. Шапокєнє (теорія і практика підготовки учителів біології до організації природоохоронної діяльності школярів). Проте проблема формування в майбутніх учителів біології фундаментальних наукових знань та практичних умінь природоохоронної діяльності залишається відкритим.

Мета статті полягає в теоретичному обгрунтуванні, розробці та експериментальній перевірці ефективних методів формування готовності майбутніх учителів біології до природоохоронної діяльності.

Виклад основного матеріалу дослідження 3 повним обгрунтуванням отриманих наукових результатів. Усвідомлення будь-якого природного явища ускладнюється без інтеграції знань із різних наук. Дотримуємося думки, що природоохоронну освіту варто будувати 3 урахуванням сучасних здобутків фундаментальних і прикладних дисциплін.

Комплексний розвиток когнітивної сфери особистості, на наш погляд, сприяє професійній лабільності, швидкій адаптації до нестандартних ситуацій. У цьому контексті важливу роль відіграє фундаменталізація освіти. Так, Г.А. Білецька звертає увагу на позицію науковців про те, що “фундаментальні поняття мають визначати об’єм та послідовність змісту навчального предмета. Фундаменталізація освіти передбачає вироблення людьми навичок та умінь самостійно знаходити і приймати відповідальні рішення в умовах невизначеності, в критичних і стресових ситуаціях, коли вони стикаються 3 новими природними й соціальними явищами” [1, 48].

В основі принципу фундаменталізації лежить поглиблення загальнофілософських, психологопедагогічних, загальнокультурних і спеціальних знань, наукового мислення, що уможливлює формування високого рівня екологічної компетентності студентської молоді. Він дозоляе виходити за рамки вузької спеціалізації, що є важливим чинником формування в майбутніх учителів біології природничо-наукової картини світу, удосконалення природоохоронних умінь та навичок.

Важливою проблемою сучасної вищої освіти 


\section{ФОРМУВАННЯ ГОТОВНОСТІ МАЙБУТНІХ УЧИТЕЛІВ БІОЛОГІЇ ДО ПРИРОДООХОРОННОЇ ДІЯЛЬНОСТІ МЕТОДОМ КЕЙСІВ}

є набуття практичного досвіду, відпрацювання навичок у режимі реального часу, встановлення зв'язку навчання 3 життям. 3 цією метою нами було використано кейс-метод. Його ефективність підтверджується результатами досліджень закордонних та вітчизняних науковців [7]. К.М. Герасименко зазначає, що ця технологія активного проблемно-ситуаційного аналізу дає змогу демонструвати академічну теорію з точки зору реальних подій, сприяє активному засвоєнню знань і навичок збору, обробки та аналізу інформації, що характеризує різні ситуації [2].

Разом із традиційними методами навчання, використання кейс-методу дає можливість створення умов для розвитку самостійної пізнавальної активності студентів в умовах “реального часу та середовища”. Однією 3 характерних особливостей цього методу $є$ співпраця за принципом “діяти вже сьогодні, але 3 думкою про завтра”, пошук альтернативних шляхів вирішення, емоційне переживання певної ситуації [7].

Схема реалізації навчальних кейсів побудована так, що на початковому етапі викладач пропонує студентам матеріали, зміст яких відображає конкретну проблему охорони навколишнього природного середовища. Далі студенти самостійно вивчають отриману інформацію та аналізують іï, збирають додаткові матеріали, порівнюють та уточнюють дані, за потреби та можливості вивчають ситуацію "на місці", консультуються 3 фахівцями, експертами. Кожен член робочої групи бере активну участь в обговоренні проблеми, виборі шляхів ¥ї вирішення. Результати презентуються у формі інформаційного повідомлення, розробки проекту чи сценарію заходів, відео-, фотозвітів. Представники різних робочих груп можуть брати участь в обговоренні висновків інших, висловлювати свої пропозиції. На кінцевому етапі проводиться підсумкова конференція, на якій озвучується висновок із вирішення конкретної проблеми, предметно обговорюються результати, враження, визначаються труднощі та успіхи.

Серед основних функцій навчальних кейсів природоохоронного змісту можемо виділити наступні:

- пізнавальна функція - передбачає розширення, поглиблення та інтеграцію знань природоохоронного змісту шляхом встановлення міжпредметних зв'язків, самостійного пошуку інформації, iї узагальнення та верифікації;

- мотиваційна функція - забезпечує формування внутрішніх потреб у збереженні біотичного різноманіття, раціонального використання ресурсів та зменшення екологічного сліду, стійких переконань, інтересів у сфері охорони природи;

- виховна функція - орієнтована на формування відповідальності за власні дії щодо навколишнього природного середовища, активної життєвої позиції, екологічної культури, професійної етики;

- організаційна функція - виражається в ефективній організації освітнього процесу в професійно-орієнтованому напрямі. Вирішення конкретної ситуації, взятої з реального життя, дає можливість студентам отримати фахові знання. При цьому викладач виконує роль куратора, модератора, який генерує питання, фіксує результати, надає консультації, забезпечує професійний супровід;

- рефлексивна функція - передбачає здійснення самоаналізу, самооцінки та самоконтролю власної діяльності, професійне самовдосконалення;

- аксіологічна функція - їі мета полягає у формуванні цінностей, орієнтованих на реалізацію засад сталого розвитку, що пов'язані зі збереженням біотичного та ландшафтного різноманіття, як основи добробуту майбутніх поколінь;

- апробаційна функція - полягає в перевірці на практиці теоретично обгрунтованих методів, алгоритмів та моделей реалізації природоохоронної діяльності;

- профорієнтаційна функція - сприяє виявленню педагогічних якостей, інтересів i здібностей кожного студента, усвідомленню правильності вибору професії, пов'язаної 3 природоохоронною діяльністю.

Під час розробки навчальних кейсів ми дотримувались загальних вимог, зокрема: відповідність меті навчання; передбачення певного рівня складності; комплексне охоплення проблеми природоохоронного змісту; актуальність для даного періоду; стимулювання пізнавального інтересу та розвитку критичного мислення, конструктивної дискусії; прогнозування декількох шляхів вирішення проблеми 3 перспективою вибору найбільш оптимального в конкретних умовах. Алгоритм типового авторського кейса унаочнено у блок-схемі (рис. 1).

3 метою підтвердження ефективності запропонованого нами підходу було проведено дворазове діагностування студентів спеціальності 014.05 Середня освіта (Біологія). Результати дозволяють констатувати динаміку змін, що спостерігалась після впровадження системи 


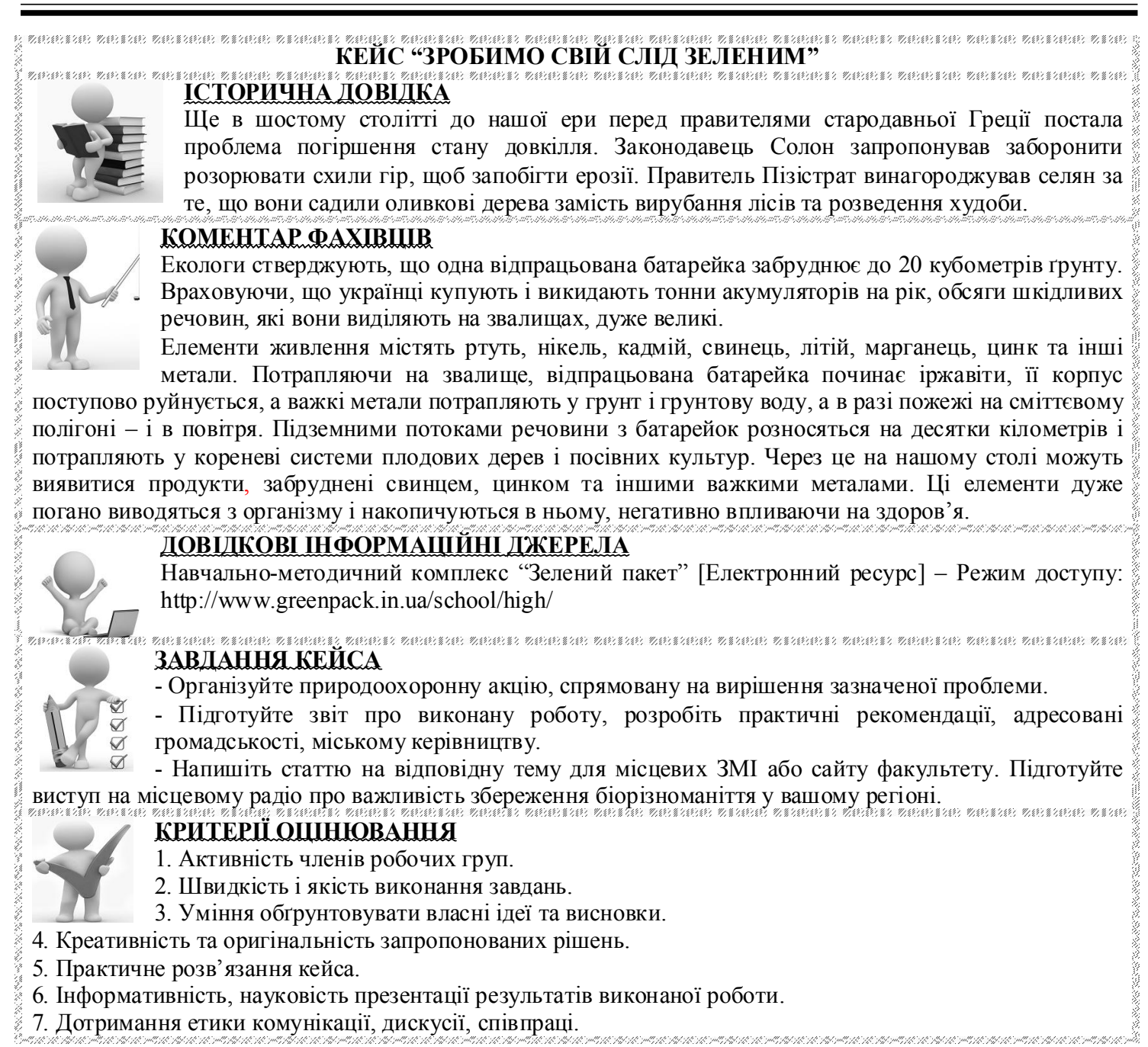

\section{Рис. 1. Приклад навчального кейса природоохоронного змісту}

навчальних кейсів природоохоронного змісту. Відсоткові показники достатнього рівня готовності до природоохоронної діяльності зросли 3 14,5\% до $36,2 \%$; кількість студентів, яким властивий середній рівень готовності, зросла 3 20,8\% до 55,5\%; кількість респондентів із низьким рівнем готовності до природоохоронної діяльності знизилась із $64,7 \%$ до $8,3 \%$. Отже, можемо констатувати ефективність використання кейсметоду у процесі професійної підготовки майбутніх учителів біології до природоохоронної діяльності.

Висновки 3 даного дослідження i перспективи подальших розвідок у даному напрямку. Вважаємо, що професійний розвиток майбутніх учителів біології реалізовуватиметься ефективніше за умови використання професійноорієнованих методів, наповнення змісту фахових дисциплін питаннями природоохоронного змісту, переходу від монодисциплінарності до інтегративності та зв'язку теорії з життям, від декларативності знань до готовності активно діяти для пізнання суті проблеми, пошуку шляхів іiї вирішення та безпосереднього розв'язання.

\section{ЛІТЕРАТУРА}

1. Білецька Г. А. Педагогічні умови інтеграції фундаментальних і професійно орієнтованих дисциплін у підготовці екологів: дис. ... канд. пед. наук: 13.00.04 / Білецька Галина Анатоліївна. Хмельницький, 2004. - 256 с.

2. Герасименко К. М. Использование технологии case-study в процессе профессиональной подготовки педагогических кадров / К. М. Герасименко // Дополнительное профессиональное образование в условияхмодернизации: материалытретьейвсероссийской научно-практической интернет-конференции / под науч. ред. М. В. Новикова. - Ярославль: Изд-во ЯГПУ им. К. Д. Ушинского, 2011. - С. $46-48$.

3. Долгоруков А. Метод case-study как современная технология профессиональноориентированного обучения [Электронный 
pecypc]. - Режим доступа: http://www.evolkov.net/ case/case.study.html.

4. Закон України "Про освіту”: від 11 червня 2008 р. [Електронній ресурс]. - Режим доступу: http://www.osvita.org.ua. - Назва з екрана.

5. Звіт WWF Жива Планета 2012: надмірне споживання спустошує Землю [Електронний pecypc]. - Режим доступу: http://wwf.panda.org/uk/ ?204759/LPR-2012 - Назва з екрана.

6. Люленко С. Громадські природоохоронні організації та напрями їх екологічної діяльності / С. Люленко // Молодь і ринок. - 2017. - № 3. C. $62-66$.

7. Самілик В. І. Формування готовності майбутніх учителів біології до природоохоронної діяльності засобом кейс-методу у процесі професійної підготовки / В. І. Самілик // Глухівські наукові читання - 2016. Актуальні питання суспільних та гуманітарних наук / Матеріали VI Міжнародної інтернет-конференції молодих учених і студентів 27 - 29 вересня 2016 р. - Глухів: РВВ Глухівського НПУ ім. О. Довженка. - 2016. - C. $83-85$.

\section{REFERENCES}

1. Biletska, H. A. (2004). Pedahohichni umovy intehratsii fundamentalnykh i profesiino oriientovanykh dystsyplin u pidhotovtsi ekolohiv [Pedagogical conditions of integration of fundamental and professionally oriented disciplines in training of future ecologists].Candidate's thesis. Khmelnytskyi, 256 p. [in Ukrainian].

2. Gerasimenko, K. M. (2011). Ispolzovanie tekhnologii case-study $\mathrm{v}$ protsesse professionalnoy podgotovki pedagogicheskikh kadrov [The use of technology case-study in the process of professional training of teaching staff]. Dopolnitelnoe professionalnoe obrazovanie $v$ usloviyakh modernizatsii: materialy tretey vserossiyskoy nauchno-prakticheskoy internet-konferentsii - The additional vocational education in the conditions of modernization: Proceedings of the 3rd All-Russian Scientific and Practical Internet Conference. (pp.4648). (Ed.). M. V. Novikov. Yaroslavl. [in Russian].

3. Dolhorukov, A. Metod case-study kak sovremennaia tekhnolohyia professyonalnooryentyrovannoho obuchenyia [Case-study method as a modern technology of vocational training]. Available at: http://www.evolkov.net/case/ case.study.html. [in Russian].

4. Zakon Ukrainy "Pro osvitu" (2008). [The Law of Ukraine "On Education"]. Available at: http:// www.osvita.org.ua. [in Ukrainian].

5. Zvit WWF Zhyva Planeta (2012). [WWF's Living Planet Report]. Available at: http:// wwf.panda.org/uk/?204759/LPR-2012. [in Ukrainian].

6. Liulenko, S. (2017). Hromadski pryrodookhoronni orhanizatsii ta napriamy yikh ekolohichnoi diialnosti [The public environmental protection organizations and their ecological activities]. Yoth \& market, vol. 3, p. 6. [in Ukrainian].

7. Samilyk, V. I. (2016). Formuvannia hotovnosti maibutnikh uchyteliv biolohii do pryrodookhoronnoi diialnosti zasobom keis-metodu u protsesi profesiinoi pidhotovky [Forming future teachers of Biology readiness to environmental protection activity by means of a case-method in the process of professional training]. Aktualni pytannia suspilnykh ta humanitarnykh nauk. Materialy VI Mizhnarodnoi internet-konferentsii molodykh uchenykh i studentiv 27-29 veresnia $2016 r$. - Topical issues of the social sciences and the humanities. - Proceedings of the VI International Internet Conference of Young Scientists and Students, September the 27-29, 2016. (pp.8385). Hlukhiv. [in Ukrainian].

Стаття надійшла до редакції 19.03.2018

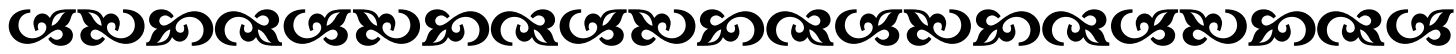

\author{
“Вчитель є служителем природи, а природа в свою чергу - єдина та щира \\ наставниия". \\ Тригорій Сковорода \\ уқраӥнський поет, білософб \\ “..Фороги власної не бійся. 3 метою у єдине злийся - хіба не ти - твоя мета?!” \\ Василь Сmyс \\ уқраӥнський поет
}

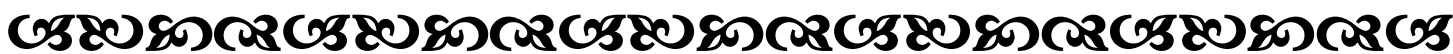

